János Kádár and Consolidation of the Socialist System (1957-1958):

With Special Reference to the Imre Nagy-trial

\title{
カーダール・ヤーノシュと「体制の強化」（1957-1958） \\ 一ナジ・イムレ裁判を中心に一
}

関西学院大学大学院荻 野 晃

\section{1. はじめに}

1956年のハンガリー事件の後で政権を掌握した カーダール(Kádár János)は、32年にわたってハン ガリーを統治することになった。カーダール時代 初期の50年代後半には、ハンガリー事件当時の首 相ナジ(Nagy Imre)の処刑に代表される反対派への 激しい弾圧が行われた。しかし、60年代前半に八 ンガリーは東欧諸国の中で最も寛容な独裁に転じ た。そして、60年代半ば以降、農業や経済メカニ ズムを中心とする改革が実施された。

60年代以降のハンガリーにおける改革路線に関 して、ハンガリーの社会学者フェヘール(Fehér Ferenc)は、路線転換の要因をソ連共産党第一書記 フルシチョフ(Nikita S. Khrushchev)が打ち出した非 スターリン化への追随だったと論じた。また、政 権成立当初からカーダールは改革を意図したが、 ソ連や党内の守旧派の反対で60年代まで実施でき なかったとイギリスのハンガリー研究者ロマック ス(Bill Lomax)は分析した。両者の研究に共通する のは、政権初期におけるカーダールの権力基盤の 脆弱さであった。(1)

本稿の目的は、ハンガリーの改革路線への移行 の端緒を探ることにある。分析にあたり、ソ連に 身柄を拘束された後のナジをめぐる問題が、ハン ガリーにおけるカーダールのリーダーシップの確 立や国内政治の基本方針と密接に結びついた点に 筆者は着目する。 89 年の体制転換以前、58年6月 のナジの裁判は、社会主義陣営の結束をはかるソ 連の指示によるものとみられてきた。(2)それに対 して、体制転換後に公開された公文書に依拠した ナジ裁判に関する研究では、カーダールの権力基 盤の強化など国内要因が重視された。 ${ }^{(3)}$ 本稿では、 ナジ裁判がハンガリーの国内政治の路線形成とい かに結びついたかを考察する。
なお、ハンガリー人の氏名は、現地の記述とお りに名字·名前の順である。

\section{2.「体制の強化」}

本論に入る前に、カーダール時代初期に関する 研究史を振り返りながら、ハンガリー事件後の国 内の状況について述べる。カーダール時代初期は 「体制の強化(konszolidáció)」の時期と称されてきた。 ハンガリー出身の歷史家フェイト(François Fejtö) はカーダール時代初期を、以下のように論じた。

第一段階「独裁の土台の再建」（1956年11 12 月）

第二段階「体制の強化」（1957 1959年）

第三段階「正常化と『カーダールのモデル』の 実現」（1960年）

とくに、第二段階について、社会主義体制の再 建の過程でのナジの処刑など反体制派への弾圧と 厳しい国内統制をフェイトは強調した。また、ア メリカのハンガリー研究者フェルカイ(Andrew Felkay)もナジ処刑に至った50年代末を「体制の強 化」と位置づけた。(4)

オルモシュ(Ormos Mária)、ウルバーン(Urbán Károly)、リップ(Ripp Zoltán)、フェティル(Fetil István)などハンガリーの歴史家による体制転換以 降のカーダール時代初期に関する研究では、フェ イトが述べた第二段階で一貫して社会主義体制の 強化が進められたのでなく、57年前半に党外から の人材を登用した経済改革が試みられたこと、改 革が頓挫した後で社会主義制度の再建、強化が進 められたこと、さらに50年代末以降に国内統制の 緩和が段階的に行われたことが指摘された。また、 彼らの研究では、「体制の強化」とは60年代の路線 転換に至るまでの時期を意味した。そして、フェ イトが論じた第二段階としての「体制の強化」を、 
ハンガリー事件以前の諸制度の再建が進んだ点に 言及して「旧体制の復活(restauráció)」と彼らは位置 づけた。(')

先行研究の成果を踏まえ、「体制の強化」は、以 下のように進行したと筆者は分析する。

第一段階「独裁の土台の再建」(1956年11 12月)

第二段階「改革の試み」（1957年1 3月）

第三段階「旧体制の復活」(1957年4月 1958年)

第四段階「緩和された旧体制の復活」 （1959 1961年）

第五段階「中道政治の実現」（1962 1963年） 従来の研究では、改革路線への転換を論じるう えで、筆者の分析による第四段階から第五段階へ の移行にあたる、61年12月の演説で「我々に反対 しない者は味方である」とカーダールが述べた時 期が重視された。(6)それに対して、筆者は第三段 階から第四段階一の移行期を重視する。移行に際 して、ナジ裁判が重要な転機になったと筆者は認 識する。以下の章で、ナジ処刑に至るまでのカー ダール政権の対応を検証することで、ナジ問題が 第三段階から第四段階へ移行する時期の国内情勢 に及ぼした影響を論じる。

\section{3.「旧体制の復活」とカーダールの権力基盤の強化}

56年11月22日にブダペシュトのユーゴスラヴィ ア大使館を出た後でソ連軍に身柄を拘束されたナ ジと彼の同調者は、ルーマニアのスナゴフで軟禁 状態に置かれていた。57年1月に党暫定執行委員 会（57年6月の党全国会議以降は政治局）のメン バーであるカーライ(Kállai Gyula)がルーマニアへ 赴き、ナジたちに自己批判してカーダール政権を 支持するよう説得を試みた。11月4日のソ連軍の 介入直前、カーダールはナジに首相を辞任させて、 ナジから新政府への支持を取り付けることを意図 していた。カーライの説得工作は、ナジを体制内 に引き戻す最後の試みであった。だが、ナジはカ ーライの説得に応じなかった。1月29日の党暫定 執行委員会の協議で、ナジへの説得が不調に終わ ったことを報告し、ナジの刑事責任を問うことを カーライは提案した。党暫定執行委員会は最終的
にナジとの妥協の道を放棄し、ナジたちのハンガ リー事件中の行動について調査することを決定し た。(72月26日の党暫定中央委員会（57年6月の党 全国会議以降は党中央委員会) の協議で、ナジと 彼の同調者を正式に逮捕する方針が固まり、彼ら を告発するための文書を作成することが決定され た。 ${ }^{(8)} 26$ 日の協議の後、カーダールと彼に近い立 場の党暫定執行委員ミュニッヒ(Münnich Ferenc)、 マロシャーン(Marosán György)、カーライが、ナ ジを起訴することで一致した。(9)4月9日に、党暫 定執行委員会がナジと彼の支持者を起訴すること を決定した。(10)決定の後、ナジたちはハンガリー 一送還された。

ナジの起訴の決定は、3月21日から28日までの カーダールを団長とするハンガリーの党および政 府代表団の訪ソの後でなされた。そのため、訪ソ 中のハンガリー代表団にナジを起訴するようソ連 が指示したと推察できる。しかしながら、先述の とおり、代表団の訪ソ以前に社会主義労働者党内 で検討されていた。ナジ問題について、ソ連が何 か具体的な決定を下した形跡はない。カーダール の訪ソ中に、ナジを起訴するハンガリーの方針を ソ連は支持したのである。

カーダールがナジの起訴を決定した要因は、軍 事介入後の国内問題の処理をハンガリーのイニシ アティヴで行おうとしたからだった。遅くともカ ーライの説得工作が失敗した後、社会主義諸国に とって潜在的脅威となるナジを厳しく処罰するこ とで、ソ連とカーダール政権は一致していた。そ の一方で、ソ連を中心とする社会主義陣営にとど まりながらも、ハンガリー事件の再発を防止する ため、事件以前のようなソ連の恐意的な内政干涉 をカーダールは抑えねばならなかった。56年2月 のフルシチョフのスターリン批判以降も第一書記 ラーコシ(Rákosi Mátyás)に固執してカーダールや ナジの復権を阻み、ハンガリー事件を回避できな かった責任が、当時の駐ハンガリー・ソ連大使ア ンドロポフ(Yuri V. Andropov)やソ連共産党中央委 員会書記スースロフ(Mihail A. Suslov)にあったこ とは、近年の研究からも明らかとなっている。(11) 
カーダール・ヤーノシュと「体制の強化」（1957-1958）ーナジ・イムレ裁判を中心に一

11月4日の軍事介入の直前に、ソ連共産党政治局 員を前にしてハンガリー事件以前のソ連のハンガ リー政策を批判し、今後はハンカリリーの国民感情 に配虑するようカーダールは要求していた。(12) ソ 連がナジ問題について干涉してくる前に、カーダ ールは自らの判断でナジを起訴する方針を固めた。 社会主義労働者党がナジの路線を否定したこと で、「旧体制の復活」の動きが進行した。ラーコシ 時代の個人崇拝こそ復活しなかったが、勤労者党 時代（ハンガリー事件の最中に解党）と同様の党 機構、政府組織、党の大衆組織が再建され、党一 国家ともいえる社会主義体制が復活した。政権の 成立当初、カーダールは経済メカニズムを中心と する改革を意図し、独立小農業者党の経済問題の 専門家だったヴァルガ(Varga István)、ラーツ(Rácz Jenő)、ボグナール(Bognár József)に57年1月から経

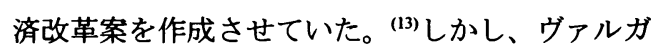
たちが作成した改革案は、6月14日の党暫定執行 委員会で検討されることなく、事実上、廃案にな

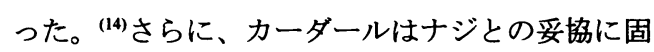
執する党暫定中央委員の排除に乗り出した。6月 27日からの党全国会議の直前に、ケベル(Köböl József)とジェネシュ(Gyenes Antal)が党暫定中央委 員を解任された。(15)

その一方で、「旧体制の復活」の時期には、カー ダールを中心に党指導部の統一がなされ、彼の党 内基盤が強化された。党全国会議で、党内に残存 する有力なスターリン主義者である元文化相レー

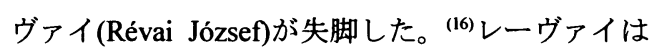
ラーコシ時代にハンガリーにおけるスターリン主 義のイデオローグだった。ラーコシに代表される 教条主義、ナジに代表される修正主義の双方に反 対する「二正面闘争(kétfrontos harc)」の原則が維持 された。(17)また、親ナジ派ながらカーダールと妥 協したフェヘール(Fehér Lajos)、アツェール(Aczél György)が、それぞれ政治局、党中央委員会にと どまった。ナジの起訴の決定を契機とする「旧体 制の復活」は、ハンガリー事件以前の状態を正常 なものとみなし、たんなる事件以前への回帰でな く、新たな路線構築の可能性を残していたのであ
る。

\section{4. ナジ裁判と「緩和された旧体制の復活」}

57年4月に社会主義労働者党はナジと彼の同調 者を起訴することを決定した後、彼らの取調べと 告発状の作成を始めた。社会主義労働者党は、57 年の秋にはナジの裁判を始めるつもりだった。8 月に政治局員ビスク(Biszku Béla)がソ連を訪問し て、裁判を始めることへの了解を得ようとした。 ソ連側はナジの裁判を行うことに反対しなかった。 しかし、ソ連軍の撤退や逮捕された政治犯の釈放 を要求する「ハンガリー問題」が議題に上ることが 確実な国連総会を9月にひかえ、さらに11月の世 界共産党・労働者党会議を前にユーゴスラヴィア との対立を回避するため、少なくとも12月か翌年 1月まで裁判を延期するようソ連はビスクに指示

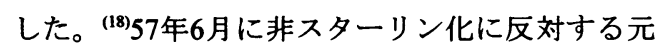
外相モロトフ(Vyacheslav M. Molotov)、副首相力 ガノヴィッチ(Lazar M. Kaganovich)などの「反党グ ループ」が失脚した後、ハンガリー事件で悪化し たソ連・ユーゴスラヴィア関係の改善が進んでい た。8月のルーマニアのスナゴフでのソ連・ユー ゴスラヴィア首脳会談で、ユーゴスラヴィア大統 領チトー(Josip B. Tito)はナジの裁判を行うことに 反対した。(19)

57年11月のモスクワにおける世界共産党・労働 者党会議で、ユーゴスラヴィア代表団はソ連を中 心とする社会主義諸国の結束を強調した共同宣言 への署名を拒否し、ソ連・ユーゴスラヴィア関係 が再び悪化した。世界共産党·労働者党会議の後、 社会主義陣営の結束をはかるソ連が、ハンガリー にナジの裁判を指示したと考えられる。しかし、 現実には、ナジ裁判の早期開廷をのぞんだのは、 ソ連でなくハンガリーであった。ユーゴスラヴィ アと対立しながらも、ナジ裁判によってハンガリ 一・ユーゴスラヴィア関係が険悪化することをン 連はのぞまなかった。世界共産党·労働者党会議 の際、フルシチョフはカーダールにナジ裁判の早 期開廷に慎重な姿勢を示した。会議の後も、駐八 ンガリー・ソ連大使グロモフ(Jevgeni I. Gromov)を 
通じて、カーダールに対ユーゴスラヴィア関係の 悪化を回避するようフルシチョフが指示していた ことが確認できる。 ${ }^{(20)} 49$ 年にラーコシがチトーの スパイの烙印を押して元外相ライク(Rajk László) を肃清し、対ユーゴスラヴィア関係を険悪化させ た経緯を踏まえても、ナジ裁判がライク裁判と同 様の結果をもたらすことをソ連が危惧したとして も不思議でない。ハンガリー事件後のソ連・ユー ゴスラヴィア対立は、あくまで国際共産主義運動 の進め方やソ連と他の社会主義国の関係をめぐる 論争であり、フルシチョフにはチトーの政権を力 で打倒する意図はなかった。さらに、カーダール がナジ裁判を行う意思を明確にしていたことは明 らかである。12月21日の党中央委員会の非公開協 議で、カーダールはナジの裁判を始めることを提 案した。党中央委員会はカーダールの提案を支持 した。(21)

カーダールはナジ裁判を始めようとした。だが、 米ソ首脳会談の開催をアメリカに呼びかけていた フルシチョフは、58年2月5日にナジ裁判の延期を 指示した。しかし、カーダールには裁判を中止す る意図はなかった。2月14日の党中央委員会で、 ナジ裁判の延期は正しい選択とはいえず、ソ連の 対外戦略や国際情勢に及ぼす影響に配慮して裁判 を延期したが、裁判を行う方針に変更はないとカ ーダールは述べた。(22)

58年4月のユーゴスラヴィア共産主義者同盟第7 回大会で採択された新綱領の内容をめぐって、ソ 連・ユーゴスラヴィア間の対立が激化した。社会 主義諸国内でのソ連のへゲモニーに対する批判、 東西陣営の解消をめざして国家や民族が主体とな る積極的平和共存を提唱した網領の草案が公表さ れると、ソ連はユーゴスラヴィアを激しく批判し た。(23)

共産主義者同盟新網領をめぐるソ連・ユーゴス ラヴィア論争の後、ナジ裁判への動きが加速した。 5月24日のワルシャワ条約機構加盟国首脳会談の ために訪ソした際、カーダールはソ連からナジ裁 判開廷への了解を取り付けたとみられる。カーダ 一ルの帰国後、5月27日の非公開協議で、政治局
はナジの裁判を始めることを確認した。 ${ }^{(24)} 6$ 月2日 のブダペシュト近郊のレアーニファルにおける非 公式会談で、党を代表してカーダールとマロシャ ーン、政府を代表してミュニッヒとビスクが、ナ ジを処刑することで合意した。(25)そして、6月6日 の党中央委員会の非公開協議で、ナジの裁判が正 式に決定された。(26)裁判は6月9日から15日にかけ て行われ、16日にナジの死刑が執行された。

カーダールがナジを処刑した要因として、ハン ガリーの歴史家リトヴァーン(Litván György)やラ イネル(Rainer M. János)が述べたように、カーダー ルは自分自身に対するオルタナティヴとして、政 権の存立に妿威となるナジの存在を容認できなか ったことが挙げられる。(27)カーダールがナジ裁判 を強行した要因を、国内問題に重きをおいて彼ら は論じた。しかしながら、カーダールがナジの処 刑を決断するうえでのソ連要因を軽視することは できない。確かに、彼らの指摘どおり、首相辞任 を拒否したナジが存在する限り、カーダールは自 らの政権の正統性を示すことができなかった。だ が、ソ連の軍事介入で社会主義陣営からの離脱が 不可能となった後で国内を安定させるために、良 好な対ソ関係とハンガリー国民の利益をいかに共 生させるかが、カーダールにとってより重要な課 題だった。

57年11月29日の党中央委員会における演説で、 カーダールはソ連を中心とする社会主義陣営の結 束、西側帝国主義勢力に加担する修正主義の危険 性を強調した。その一方で、カーダールは「ハン ガリーの労働者階級の利益と国際的な労働者階級 の利益は二つの異なるものでなく、同一であると いうのが我々の考えである。ハンガリーの特性と ハンガリーの労働者階級の立場が尊重されるなら ば、国際的な労働者階級の利益の追求に我々は寄 与することができ、我々が国際的な労働者階級の 利益に反するようなことをすれば、間違いなく八 ンガリーの労働者階級の利益を損なうことになる という原則に基づき、我々は行動する。」と述べ

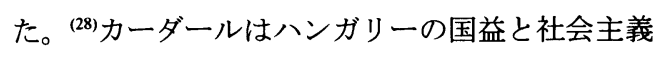
諸国の利益を調整できると説いた。具体的には、 
カーダール・ヤーノシュと「体制の強化」（1957-1958）ーナジ・イムレ裁判を中心に一

ソ連型社会主義の根幹を維持しながら、ハンガリ 一の内情に適応した社会主義路線を打ち出す意思 をカーダールは示したといえる。

ハンガリー事件のような事態を絽り返さないた め、権力を行使して党の指導的役割を徹底させる ことは不可避だった。だが、たんにハンガリー事 件以前の体制に回帰するのでなく、国内の統制を 緩和した形での一党支配体制を構築する必要があ った。市民が党の指導的役割やイデオロギーに異 議を唱えないかぎり、党が市民生活に干涉しない 方針、いわば「緩和された旧体制の復活(enyhített restauráció)」への転換をカーダールは意図した。(29) 党一国家と市民生活の共存を実現させるには、 国内における党の指導的役割の強化のみならず、 ソ連の内政干涉を最小限に抑える必要があった。 そのため、カーダールは社会主義陣営内部におけ るハンガリーの立場を強化しなければならなかっ た。ハンガリーがナジの裁判を引き延ばせば、ソ 連がカーダールの指導力に問題があると判断し、 内政干涉を強めてくることが予想された。57年か ら58年の時点で、ナジ裁判が国際情勢に及ぼす影

響を考慮して、裁判の延期をソ連は指示していた。 だが、ソ連は裁判そのものに反対していたのでは なかった。ユーゴスラヴィアがハンガリーの蜂起 を「国民の革命」と呼び、反革命に加担したナジを 自国の大使館で保護したと、ハンガリー事件当時 のナジとユーゴスラヴィアをソ連は結びつけた。(30) いずれにせよ、社会主義陣営内部で修正主義批判 が激しさを増す状況では、カーダールの意思にか かわりなく、ナジを厳重に処罰することは避けら れなかったといえる。他方、国内の長期的な安定 のためには、経済、農業に関するナジの考えを政 策に反映させる必要があった。政策転換の前段階 で、ナジを処刑することによって、ハンガリーの ワルシャワ条約機構からの離脱と一党支配体制の 放棄を宣言したナジとの断絶性をカーダールはソ 連に明確な形で示そうとした。

ナジ処刑の後、ハンガリー事件で逮捕された政 治犯一の恩赦が段階的に実施された。また、作家 などの知識人や教会との対話が始まった。さらに、
テロによらず、強制供出制を廃止した農業の再集 団化にカーダール政権は着手した。 ${ }^{(31)} 60$ 年代に入 ると、カーダールを中心とする党指導部の内政に 対するソ連の干涉は少なくなった。(32)「緩和され た旧体制の復活」に転じるうえで、ナジ処刑は重 要な契機となったのである。

\section{5. おわりに}

カーダール時代初期の「体制の強化」は、「緩和 された旧体制の復活」から、党が権力を独占する 体制を堅持しながら国内の改革を進める、いわば 「中道政治(centrumpolitika)の寒現」の段階をへて終 結した。そして、60年代半ばから農業や経済メカ ニズムの改革が始まった。カーダールの路線は、 ラーコシが築いた社会主義制度にナジの改革構想 を取り入れていくものだった。ライネルが論じた ように、改革の生みの親であるナジ、一党支配体 制の象徴としてのラーコシの双方を葬ることで、 カーダールは自らの路線を確立した。(33)

リトヴァーンをはじめ、体制転換後のハンガリ 一の史学界では、ナジ処刑に象徴される反体制派 への激しい弾圧に対するカーダールへの批判が根 強い。実際に、ナジを否定した「旧体制の復活」の 段階で、社会主義労働者党は勤労者党時代との連 続性を残すことになった。そのため、60年代以降 のハンガリーの社会主義は、当初からソ連型社会 主義のオルタナティヴへと発展する可能性のない、 ソ連型社会主義の緩和された形態に過ぎなかった。 しかしながら、50年代後半に行われた弾圧の不当 性のみを取り上げて32年間に及ぶカーダールの国 内統治の全体に対する批判とすることはできない。 ハンガリー事件後、国内の安定に果たしたカーダ 一ルの役割は大きい。ハンガリー事件の後で一党 支配体制が再建されたが、公的機関への党の統制 や党員以外の人材登用の制限は、事件以前より緩

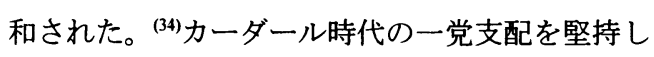
た上からの改革は、ソ連の軍事介入後のハンガリ 一において、唯一の国益擁護の手段であったこと は否定しようがない。当時、カーダールより良い 選択肢など存在しなかった。(35) 
ハンガリーにおける60年代の路線転換は、ソ連 で第二波の非スターリン化が打ち出された時期と 重なっており、フルシチョフの支持を得た有利な 国際環境の下でなされた。しかし、路線転換は、 フェヘール・フェレンツが述ベたようなフルシチ ヨフの非スターリン化へのたんなる追随ではなか った。盲目的な対ソ追随をはかる教条主義、急速 なソ連離れをはかる修正主義の双方を否定した中 道志向の党指導部が、58年の段階で形成された意 義は大きかった。カーダール政権下における改革 路線の端緒は、ナジ裁判を機に「旧体制の復活」か ら「緩和された旧体制の復活」へと移行した時期に あったのである。

\section{<注 $>$}

(1) Ferenc Fehér, "Kádárism as the Model State of Khrushchevism," Telos, No.40, Summer 1979, pp.19-31; Bill Lomax, "The Hungarian Revolution of 1956 and the Origins of the Kádár Regime," Studies in Comparative Communism, Vol.18, 2-3, 1985, pp.87-113.

(2) William Shawcross, Crime and Compromise: János Kádár and the Politics of Hungary since Revolution (New York: E. P. Dutton, 1974), pp.246-248; Andrew Felkay, Hungary and the USSR, 1956-1988: Kádár's Political Leadership (Westport, Conneticut: Greenwood Press, 1989), pp.119-123; フランソワ・フェイト著、いわ な・やすのり訳『ブダペスト蜂起 1956年 一最初の反全体主義革命』空社、1990年、 167ー172頁（原著は1981年にフランス語で出 版)。

(3) György Litván, 'The Political Background of the Imre Nagy Trial,' in Alajos Dornbach, The Secret Trial of Imre Nagy (Westport, Conneticut: Praeger, 1994), pp.161-182; Rainer M. János, Nagy Imre 1953-1958: Politikai életrajz II [ナジ・イムレ伝 2 1953-1958 年](Budapest: 1956-os Intézet, 1999), 373-391.o.

(4) フェイト、前掲書、177-187頁、Andrew
Felkay, op.cit., pp.103-123.

(5) Ormos Mária, “A konszolidáció problémái 1956 és 1958 között[体制の強化の諸問題 19561958]," Társadalmi Szemle, 44, 8-9, 1989, 4871.o.; Ripp Zoltán, “A sztálinizmus rendszerének és restaurációjának elvi kérdéseiröl[スターリン 主義体制及び旧体制の復活の本質的な問題], Múltunk, 35, 1, 1990, 129-140.o.; Ripp Zoltán, “Restauráció és centrumpolitika [旧体制の復活 と中道政治],” Rubicon, 1998, 1, 6-11.o.; Urbán Károly, "A kádári konszolidáció második szakasza: Változások az MSZMP politikai irányvonalában 1957 elején [カーダールの体制 強化の第二段階 -1957 年初頭における社会 主義労働者党の基本方針の変化], Társadalmi Szemle, 48, 8-9, 1993, 115-128.o.; Fetil István, "Kormánypolitika, 1956.November 4-1957.július [[政府の政策 1956 年11月 4日 - 1957年7月 1 日]," História, 1995, 9-10, 13-14.o.

(6) Andrew Felkay, op.cit., p.154; ジュルコー・ラ 一スロー著、南塚信吾、田中一生、家田 修 訳『カーダール・ヤーノシュ伝 一現代ハン ガリ一史の証人』恒文社、1985年、275頁。

(7) Némethné Vágyi Karola, Urbán Károly, eds., $A$ Magyar Szocialista Munkáspárt ideiglenes vezető testületeinek jegyzőkönyvei II [ハンガリー社会 主義労働者党暫定指導部議事録2] (Budapest: Intera, 1993), 75-79.o. (以下、 $A z \quad M S Z M P$ jegyzökönyvei と略記。)

(8) Ibid., 226.o.

（9）3月8、9日にルーマニアでカーライと会談し たソ連共産党国際部長ポノマ.リヨフ(Boris N. Ponomarev)によるソ連共産党中央委員会への 報告、Vjacseszlav Szereda, Alekszandr Sztikalin, eds., Hiányzó lapok történetéböl: Dokumentumok a volt SZKP KB levéltárából [歷史から抜けたぺ ージ 1956年 一旧ソ連共産党中央委員会資 料集] (Budapest: Móra Ferenc Könyvkiadó, 1993), 260-263.o.を参照。

(10) Az MSZMP jegyzökönyvei III, 69-70.o. 
カーダール・ヤーノシュと「体制の強化」（1957-1958）ーナジ・イムし裁判を中心に一

(11) Alekszandr Sztikalin, “A szovjet nagykövetség és az MDP-n belüli harc 1956-ban [ソ連大使館と 1956年のハンガリー勤労者党の内部抗争], ” Múltunk, 43, 2, 1998, 23-49.o.

(12) Vjacseszlav Szereda, Rainer M. János, eds., Döntés a Kremlben, 1956: A szovjet pártelnökség vitái Magyarországról [クレムリンにおける決 定 1956年 一ハンガリーに関するソ連党指 導部の論争] (Budapest: 1956-os Intézet, 1996), 88-95.o.

(13)Az MSZMP és a többpártrendszer 1957-ben: A Varga-féle reformbizottság és a pártvezetés. Közli: Némethné Vágyi Karola, Urbán Károly [ネーメ トネー・ヴァージ・カロラ、ウルバーン・カ 一ロイ「資料：1957年の社会主義労働者党と 複数政党制 一ヴァルガ改革委員会と党指導 部」]. In Társadalmi Szemle, 48, 1993, 8-9, 146149.o.

(14)Az MSZMP jegyzökönyveiIV, 118-119.o.

(15)Ibid., 266-268.o.

(16) ジュルコー・ラースロー、前掲書、245-246 頁。

(17) 56年12月 5日の党暫定中央委員会の決議、 $A z$ MSZMP jegyzökönyvei I, 238-246.o.を参照。

(18) 57年8月 26日にソ連共産党中央委員会を代表 してビスクと会談したアンドロポフ、ルデン コ(Roman A. Rudenko)、イヴァシュティン (Pjotr I. Ivashutin)の報告、Gál Éva, Hegedüs B. András, Litván György, Rainer M. János, eds., $A$ „Jelcin-dosszié”: Szovjet dokumentumok 1956-ról [「エリツィン・ファイル」ーソヴィエト資 料集 1956年] (Budapest: Századvég・1956-os Intézet, 1993), 199-200.o.

(19)8月29日のアンドロポフによるナジ問題に関 する記録、ibid., 202.o.

(20)57年12月28日の政治局の協議におけるカーダ 一ルの報告、Magyar Országos Levéltár(以下 $M O L$ と略記), Budapest: MDP-MSZMP Iratok [ハンガリー国立公文書館、ブダペシュト、 ハンガリー勤労者党一ハンガリー社会主義労
働者党文書] 288.f.5/59.ő.e.

(21) $M O L$ 288.f.4/14/1.o.e.

(22) $M O L$ 288.f.4/15/1.o.e.

(23) 網領草案（ハンガリー語版）、A Jugoszláv Kommunista Szövetség programtervezete (Novi Sad: Fórum, 1958). ソ連の網領草案批判の英語 訳、Vaclav L. Benes, Robert F. Bymes, Nicolas Spulber, eds., The Second Soviet-Yugoslav Dispute: Full Text of Main Documents April-June 1958 with an Introductory Analysis (Bloomington: Indiana University Publishers, 1959), pp.95-130.

(24)MOL 288.f.5/80.0̃.e. 5月27日の協議の決議では、 ナジと彼の同調者について、Xグループとし か記されず、また具体的な議論の内容も議事 録として残されていない。

(25)György Litván, op.cit., pp.176-177.

(26) MOL 288.f.4/17.0.e.6月6日の協議の決議でも、 ナジの名前は記されていない。

(27)György Litván, op.cit., p.178; Rainer M. János, op.cit., 390.0.

(28) $M O L$ 288.f.4/14.ő.e.

(29) Ripp Zoltán, "Restauráció és centrumpolitika," 9 11.0.

(30)5月9日のソ連共産党中央委員会のユーゴスラ ヴィア共産主義者同盟中央委員会への書簡、 MOL 288.f.9/1958/20.ő.e.

(31)Romsics Ignác, Magyarország története a XX.században [20世紀ハンガリー史] (Budapest: Osiris Kiadó, 1999), 414-419.o.; Ormos Mária, op.cit., 69-70.o.

(32) Nyers Rezső, “Kádár János és a reformok [カー ダール・ヤーノシュと諸改革],” Rubicon, 2000, 7-8, 52.0.

(33) Rainer M. János, op.cit., 390.0.57年2月26日に、 社会主義労働者党暫定中央委員会はラーコシ の5年間の帰国禁止を決定した。Az MSZMP jegyzökönyvei II, 366-368.o.

(34) Földes György, Hatalom és mozgalom 1956-1989 [権力と運動 1956-1989] (Budapest: ReformKossuth, 1989), 56-57.o. 
カーダール・ヤーノシュと「体制の強化」（1957-1958）ーナジ・イムし裁判を中心に一

(35)Kopátsy Sándor, “Kádár János történelmi jelentősége [カーダール・ヤーノシュの歷史的 意義]," Rubicon, 2000, 6, 49.o. 
János Kádár and Consolidation of the Socialist System (1957-1958):

With Special Reference to the Imre Nagy-trial

Akira Ogino

(Graduate School of Law, Kwansei Gakuin University)

\section{SUMMARY}

The aim of this paper is to examine the beginning of the reformer-line in Hungary. Hungary carried out reforms of its agricultural and economic systems after the mid 1960s. The author analyses how the Imre Nagy-problem influenced Hungarian domestic policy. Nagy was the Prime Minister during the Hungarian Revolution of 1956 and declared a renunciation of the one-party rule and a withdrawal from the Warsaw Pact. The Soviet army arrested him after the military intervention in Hungary of November 1956.

After the Soviet military intervention, János Kádár, the First Secretary of the Hungarian Socialist Workers' Party, took over the reins of the government with the intention of domestic reform. But he couldn't carry out the reform because of the unstable domestic situation and relations with the Soviet Union. He had to restrain the Soviet Union from intervention in internal affairs in Hungary on the condition that he established the reformer-line. So he consolidated his hold on the country by oppressing opponents and restoring the old socialist system.

Kádár executed Nagy in June of 1958. He took the initiative in the execution without instruction from the Soviet Union. Nagy's execution was the climax of the restoration of the socialist system after the Hungarian Revolution. Kádár tried to show the Soviet Union that executing Nagy had discontinued Nagy's radical reform. After the Nagytrial he gradually loosened domestic controls and established the reformer-line, within the one-party rule in the early of 1960s. The first step of Hungarian reformer-line in the Kádár-era was to restore the socialist system at the end of 1950s.

Key Word: Restoration of the old socialist system

The Nagy-trial

Consolidation of the socialist system 